\title{
Pathological and radiological irregularities in patients with chronic kidney disease - An observational study
}

\author{
Dushyant Pawar', Vinayak Bhoi ${ }^{2}$, Shital Pawar ${ }^{3}$, Dilip Patil ${ }^{4}$ \\ ${ }^{1}$ Associate Professor, ${ }^{4}$ Professor and Head, Department of Medicine, ${ }^{3}$ Tutor, Department of Community Medicine, \\ JMFs ACPM Medical College, Dhule, ${ }^{2}$ Senior Resident, Department of Medicine, Bharati Vidyapeeth Medical College, \\ Pune, Maharashtra, India
}

Background: Chronic kidney disease (CKD) encompasses a spectrum of different pathophysiologic processes associated with abnormal renal function and progressive decline in glomerular filtration rate (GFR). Aims and Objectives: The objectives of the study are 1) to assess basic tests and kidney function tests in patients with CKD, (2) to assess coagulation profile, sugar levels, and platelets levels in patients of CKD, (3) to do the urine analysis in patients with CKD, and (4) to assess GFR among the study population. Materials and Methods: After taking the informed consent, detailed history was taken and clinical examination of patient was done. Pathological tests such as hemogram, renal function tests, liver function tests, coagulation profile, blood sugar levels, urine routine, and microscopy were performed. Ultrasonography of abdomen and pelvis was done. Correlation was done between severity of sepsis and mortality in patients. Results: Anemia was moderate $(7-8.9 \mathrm{~g} / \mathrm{dl})$ in $38 \%$, mild $(9-10.9 \mathrm{~g} / \mathrm{dl})$ in $31 \%$, while severe $(<6.9)$ in 29 patients, that is, $29 \%$. Thrombocytopenia was present in $58 \%$ of patients. Mean serum albumin in patients was $2.67 \pm 0.551 \mathrm{mg} / \mathrm{dl}$; serum globulin was $3.89 \pm 0.345 \mathrm{mg} / \mathrm{dl}$. Mean blood sugar of study subjects was $127.41 \pm 61.387 \mathrm{mg} / \mathrm{dl}$ fasting, $199.67 \pm 114.827 \mathrm{mg} / \mathrm{dl}$ post-prandial, and mean glycated hemoglobin was $5.63 \pm 1.668$. On ultrasound acute pyelonephritis, $25(25 \%)$ was the most common finding. Conclusion: Correlation of clinical findings with pathological and radiological findings is very important in patients with CKD. Severity of sepsis directly correlates with mortality of patients.

Key words: Chronic kidney disease; Glomerular filtration rate; Pathological; Radiological, sepsis

\section{INTRODUCTION}

Chronic kidney disease (CKD) is the $12^{\text {th }}$ highest cause of death and $17^{\text {th }}$ highest cause of disability worldwide. ${ }^{1}$ Understanding the entire depth of kidney disease becomes an integral part of preventing other organ damages as kidney damage is root cause for the most of them. Up to $90 \%$ of kidney function may be lost before symptoms are present, so annual checking of those at risk is essential. ${ }^{2}$ Kidney damage for $\geq 3$ months as defined by structural or functional abnormalities of the kidney, with or without decreased glomerular filtration rate (GFR), that can lead to decreased GFR, manifest by either: Pathological abnormalities or GFR $<60 \mathrm{ml} / \mathrm{min} / 1.73 \mathrm{~m}^{2}$ for $\geq 3$ months, with or without kidney damage or markers of kidney damage, including abnormalities in imaging tests. $^{3}$

\section{Aims and objectives}

The objectives of the study are as follows:

1. To assess basic tests and kidney function tests in patients with CKD

2. To assess coagulation profile, sugar levels, and platelets levels in patients of CKD 
3. To do the urine analysis in patients with CKD

4. To assess GFR among the study population.

\section{MATERIALS AND METHODS}

\section{Study design}

This was a observational study.

\section{Sample size}

The sample size was 100 .

\section{Sampling technique}

This was simple random sampling.

\section{Inclusion criteria}

The following criteria were included in the study:

a. Patients more than 18 year of age

b. Male and female patients

c. Patients who give valid informed written consent for the study

d. Patients fulfilling the Kidney Disease Improving Global Outcome (2012) criteria for CKD.

\section{Exclusion criteria}

Patients $<18$ year of age, HIV, hepatitis B surface antigen, and hepatitis $C$ virus positive patients were excluded from the study.

\section{Procedure}

After taking informed consent, detailed history was taken regarding the disease. A detailed clinical examination was done of all the study population. Routine investigations were done as and when required.

Following blood investigations were done:

- Hemogram

- Acute phase reactant: Erythrocyte sedimentation rate/C-reactive protein (CRP)

- Renal function tests: Creatinine/blood urea nitrogen (BUN)

- Serum electrolytes: $\left(\mathrm{Na}^{+} / \mathrm{K}^{+} / \mathrm{Ca}^{++} / \mathrm{Po}_{4}^{-}\right)$

- Liver function tests: Bilirubin: (Total/direct/indirect), serum glutamic oxaloacetic transaminase (SGOT), serum glutamic pyruvic transaminase (SGPT), and proteins: (Total/albumin/globulin/A: G)

- Coagulation profile: Bleeding time (BT), clotting time (CT), activated partial prothrombin time (aPTT), prothrombin time (PT), and international normalized ratio

- Blood sugar levels: Fasting (F) and post-prandial

- Glycated hemoglobin (HbA1C)

- Urine examination: Routine and microscopy.

\section{RESULTS}

In our study, mean total leukocyte count was 20031.05 4388.859 ranging from 15600 to 37800. Mean platelet count of study population was $14.28 \pm 3.761$. The mean creatinine level was $2.09 \pm 1.848$, maximum levels were $16 \mathrm{mg} / \mathrm{dl}$ were as the minimum levels were $0.9 \mathrm{mg} / \mathrm{dl}$. Mean BUN 113.57 \pm 29.158 ranging within 34-229 (Table 1).

In present study, mean BT, CT, PT HbA1C was $3.86 \pm 1.064,5.49 \pm 1.291,18.37 \pm 6.170,5.63 \pm 1.668$ respectively (Table 2 ).

Amongst USG findings, acute pyelonephritis was seen in $25 \%$, small kidney was seen in $15 \%$, renal stone with hydronephrosis and cystitis was seen in 11\% (Table 3).

Sepsis was seen in 66 patients, septic shock was seen in $34 \%$ patients (Table 4 ).

The eGFR values of the current study compared with other studies are shown in Table 5.

According to WHO Anemia classification, in present study, 38 patients were having moderate anemia, 31 were having mild anemia, 29 were having severe anemia. Only Hemoglobin of 2 patients was within normal range (Chart 1). Majority of patients had platelet count between 1 lakh to 1.5 lakh. Platelet count more than 2 lakhs was found only in 2 patients (Chart 2).

In urine examination findings were:

1. Appearance of urine - cloudy in $56 \%$, while turbid in $37 \%$ and $7 \%$ patients had clear urine

2. Color of urine - In this study, urinary examination finding revealed white color urine in $52 \%$ patients, pale yellow color in 39\% patients, and red urine was in $9 \%$ patients

3. Protein/albumin - Urinary proteins were $2+$ in $45 \%$ patients while $42 \%$ had $3+$ proteins in urine. All study subjects had proteinuria. This universal finding was ranging from trace to $4+$

4. Urine sugar - Glycosuria was present in $48 \%$ CKD patients having urosepsis

5. Red blood cells (RBCs) in urine - RBC's in urine was observed microscopically in 51\% patients

6. Pus cells - In this study of CKD with urosepsis, urine examination of $38(38 \%)$ patients had more than 140 pus cells, that is, abundant pus cells and $100 \%$ patients had pus cells in urine

7. Casts - 91\% patients were had urinary casts which were white blood cell (WBC) cast, Granular cast, and $\mathrm{RBC}$ cast. Out of that WBC casts were predominant 
in $53 \%$ patients, $\mathrm{f} / \mathrm{b}$ granular casts $29 \%$, and $\mathrm{RBC}$ casts in $9 \%$

8. Out of total 100 patients urine culture, maximum growth of $52 \%$ of Escherichia coli was seen, $11 \%$ had growth of proteus, while Klebsiella and Pseudomonas growth was observed in $10 \%$ and $8 \%$ patients, respectively.

\section{DISCUSSION}

The present study is an observational study of total 100 patients conducted in the department of general medicine in a tertiary care institute. In the present study, patients had $9.01 \pm 1.997 \mathrm{~g} / \mathrm{dl}$ mean hemoglobin $(\mathrm{Hb})$. Anemia was a universal finding in all patients, with maximum patients having moderate anemia, 38 patients, that is, 38\%, followed by mild anemia, in 31 patients, that is, 31\%, while severs anemia was present in 29 patients, that is, $29 \%$. Only $2(2 \%)$ patients had $\mathrm{Hb}$ in normal range.

The results of our study were similar with Bhattacharjee et al., ${ }^{4}$ Sathyan et al., ${ }^{5}$ and Afshar et al. ${ }^{6}$ However, James et al., ${ }^{7}$ did not found $\mathrm{Hb}$ level $<11.9$ in any of the patients in their study.

In our study, mean total leukocyte count was 20031.05 44388.859 ranging from 15600 to 37800. Similar findings were seen in Tambo et al., ${ }^{8}$ found leukocytosis in their study and Mansur et al., who found leukocytes $(1000 / \mu \mathrm{l}) 15 \pm 6$.
Mean platelet count of study population was $14.28 \pm 3.761$ $(\times 10000)$. Thrombocytopenia was present in $58 \%$ of patients with the most patients had platelet in range of 1-1.49 lakhs, that is, 45 patients, $45-13 \%$ had platelets $<1$ lakh.

Buonaiuto et al. ${ }^{10}$ noted thrombocytopenia in $14.3 \%$ cases of their study and Mansur et al., ${ }^{9}$ found platelets $(1000 / \mu \mathrm{l})$

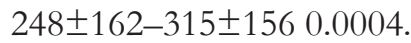

In our study, mean creatinine level was 2.09 \pm 1.848 maximum 16 and minimum $0.9 \mathrm{mg} / \mathrm{dl}$. Mean BUN $113.57 \pm 29.158$ ranging within 34-229. This results were consistent with Umesha et al., ${ }^{11}$ and Tambo et al. ${ }^{8}$

Mean serum albumin in patients was $2.67 \pm 0.551 \mathrm{mg} / \mathrm{dl}$; serum globulin was $3.89 \pm 0.345 \mathrm{mg} / \mathrm{dl}$ while total protein was $6.02 \pm 0.651 \mathrm{mg} / \mathrm{dl}$. A/G ratio was $1.528 \pm 0.6632$. Other similar studies of Sr. albumin $(\mathrm{g} / \mathrm{dl})$ are mentioned below:

In this study of CKD with urosepsis, urine examination of $38(38 \%)$ patients had more than 140 pus cells, that is, abundant pus cells and $100 \%$ patients had pus cells in urine. Urinary proteins were $2+$ in $45 \%$ patients while $42 \%$ had $3+$ proteins in urine. All study subjects had proteinuria ranging from trace to $4+$. About $48 \%$ CKD patients had sugar in urine. RBC's in urine was present in 51\% patients. About $91 \%$ patients had urinary casts which were WBC cast, granular cast, and RBC cast. Out of that WBC casts were predominant in 53\% patients, followed by granular casts $29 \%$ and RBC casts in $9 \%$.

\section{Table 1: Investigations of study subjects}

\begin{tabular}{|c|c|c|c|c|c|}
\hline Parameters & n & Minimum & Maximum & Mean & SD ( \pm ) \\
\hline qSOFA Score & 100 & 1 & 3 & 1.60 & 0.550 \\
\hline $\mathrm{HB}$ & 100 & 5 & 16 & 9.01 & 1.997 \\
\hline TLC & 100 & 15600 & 37800 & 20031.05 & 4388.859 \\
\hline Platelet (×10000) & 100 & 7 & 24 & 14.28 & 3.761 \\
\hline РCT (ng/ml) & 100 & 0.9 & 16 & 7.59 & 3.9 \\
\hline CREAT & 100 & 1 & 9 & 2.09 & 1.848 \\
\hline BUN & 100 & 34 & 229 & 113.57 & 29.158 \\
\hline $\mathrm{K}^{+}$ & 100 & 3 & 7 & 5.53 & 0.758 \\
\hline $\mathrm{Ca}^{++}$ & 100 & 8 & 10 & 8.51 & 0.541 \\
\hline $\mathrm{PO}^{-}$ & 100 & 3 & 7 & 6.03 & 0.481 \\
\hline Bilirubin total & 100 & 1 & 3 & 1.12 & 0.409 \\
\hline Direct & 100 & 0 & 2 & 0.11 & 0.373 \\
\hline Indirect & 100 & 0 & 3 & 0.98 & 0.284 \\
\hline SGOT & 100 & 20 & 152 & 40.64 & 33.561 \\
\hline Serum globulin & 100 & 2 & 4 & 3.89 & 0.345 \\
\hline Serum albumin & 100 & 1 & 3 & 2.67 & 0.551 \\
\hline Total protein & 100 & 4 & 7 & 6.02 & 0.651 \\
\hline $\mathrm{A} / \mathrm{G}$ ratio & 100 & 1.0 & 5.4 & 1.528 & 0.6632 \\
\hline
\end{tabular}

qSOFA: Quick sequential organ failure assessment, HB: Hemoglobin, TLC: Total leucocyte count, PCT: Procalcitonin, BUN: Blood urea nitrogen, SGOT: Serum glutamic oxaloacetic transaminase, SGPT: Serum glutamic pyruvic transaminase, ALP: Alkaline phosphatase 


\begin{tabular}{|c|c|c|c|c|c|}
\hline Parameters & $n$ & Minimum & Maximum & Mean & SD \\
\hline BT & 100 & 3 & 8 & 3.86 & 1.064 \\
\hline $\mathrm{CT}$ & 100 & 2 & 10 & 5.49 & 1.291 \\
\hline PT & 100 & 13 & 43 & 18.37 & 6.170 \\
\hline aPTT & 100 & 30 & 38 & 32.58 & 1.939 \\
\hline FBS & 100 & 68 & 385 & 148.41 & 79.176 \\
\hline PPBS & 100 & 100 & 458 & 224.44 & 123.788 \\
\hline $\mathrm{HbA} 1 \mathrm{C}$ & 100 & 3 & 10 & 5.63 & 1.668 \\
\hline
\end{tabular}

BT: Bleeding time, CT: Clotting time, aPTT: Activated partial prothrombin time, PT: Prothrombin time, FBS: Fasting blood sugar, PPBS: Post-prandial blood sugar, $\mathrm{HbA} 1 \mathrm{C}$ : Glycated hemoglobin

\section{Table 3: USG abdomen findings in patients}

\begin{tabular}{lcc}
\hline Finding & Frequency & Percent \\
\hline APN & 25 & 25.0 \\
Small kidney & 15 & 15 \\
Renal stone with HN & 11 & 11 \\
Cystitis & 11 & 11.0 \\
Ureteric calculi, HN HU & 9 & 9.0 \\
Stent in situ & 9 & 9.0 \\
Renal abscess & 7 & 7.0 \\
Renal papillary necrosis & 6 & 6 \\
EPN & 3 & 3.0 \\
Prostatic abscess & 2 & 2.0 \\
Bladder tumor & 2 & 2.0 \\
Total & 100 & 100.0 \\
\hline
\end{tabular}

USG: Ultrasound, HU: Hounsfield units, EPN: Emphysematous pyelonephritis, APN: Acute pyelonephritis

\begin{tabular}{lccc}
$\begin{array}{l}\text { Table 4: Correlation of severity of sepsis and } \\
\text { mortality in patients }\end{array}$ & Total \\
\cline { 2 - 3 } $\begin{array}{l}\text { Severity of } \\
\text { sepsis }\end{array}$ & Mortality & \\
\cline { 2 - 3 } & $\mathbf{N}$ & $\mathbf{Y}$ & \\
\hline $\begin{array}{l}\text { Severity of sepsis } \\
\text { Sepsis } \\
\text { N }\end{array}$ & 59 & 7 & 66 \\
$\quad \%$ & 89.4 & 10.6 & 100.0 \\
$\begin{array}{l}\text { Septic shock } \\
\text { N }\end{array}$ & 14 & 20 & \\
$\%$ & 41.2 & 58.8 & 100.0 \\
Total & & & \\
$N$ & 73 & 27 & 100 \\
$\%$ & 73.0 & 27.0 & 100.0 \\
\hline P=0.001 (S) & & & \\
& & &
\end{tabular}

Table 5: Comparision of eGFR with other studies

\begin{tabular}{lcccc}
\hline $\begin{array}{l}\text { Author and } \\
\text { year of } \\
\text { study }\end{array}$ & \multicolumn{4}{c}{ eGFR $\left(\mathbf{m l} / \mathbf{m i n} / \mathbf{1 . 7 3} \mathbf{~ m}^{2}\right)$} \\
\cline { 2 - 5 } & $\mathbf{6 0}$ & $\mathbf{4 5 - 5 9}$ & $\mathbf{3 0 - 4 4}$ & $<30$ \\
\hline $\begin{array}{l}\text { Wang et al. } \\
(2011)^{12}\end{array}$ & $4.10 \pm 0.02$ & $4.04 \pm 0.02$ & $3.98 \pm 0.05$ \\
James et al. & $3.7(0.4)$ & $3.6(0.5)$ & $3.6(0.5)$ & $3.5(0.5)$ \\
$(2008)^{7}$ & & $2.8 \pm 0.7$ & \\
$\begin{array}{l}\text { Tambo et al. } \\
(2013)^{8}\end{array}$ & & & \\
$\begin{array}{l}\text { Present } \\
\text { study }\end{array}$ & & $2.67 \pm 0.551$ & \\
\hline
\end{tabular}

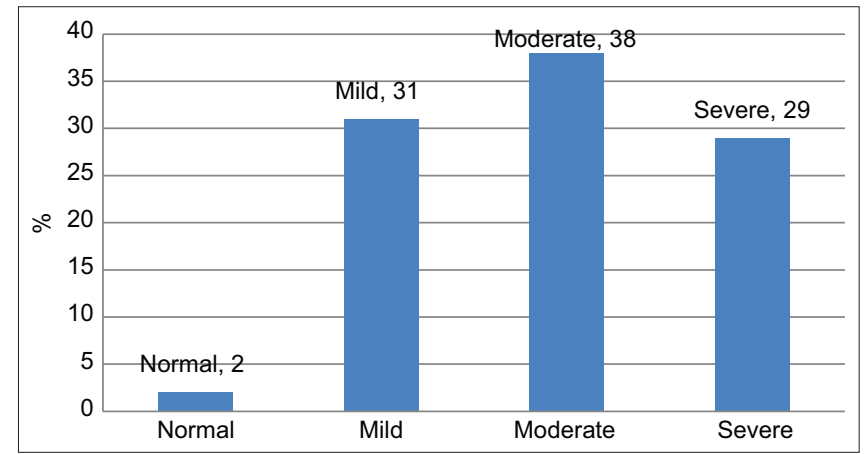

Chart 1: The World Health Organization anemia classification in the study subjects



Chart 2: Platelet range among study subjects

Buonaiuto et al., ${ }^{10}$ found similar results of pyuria and microscopic hematuria in their study, Tambo et al., ${ }^{8}$ also observed pyuria in their study.

In our study, serum procalcitonin (PCT) level ranging from 0.9 to $16 \mathrm{ng} / \mathrm{ml}$ with mean of $7.59 \pm 3.9$. Similar findings were noted by van Nieuwkoop et al., ${ }^{13}$ Meisner (2014), ${ }^{14}$ Uzzan et al., ${ }^{15}$ and Sugimoto et al., ${ }^{16}$ who found PCT as a good marker for diagnosis urosepsis.

Luzzani et al., ${ }^{17}$ and Simon et al. ${ }^{18}$ found PCT more reliable than the acute-phase protein CRP and Mansur et al., ${ }^{9}$ also had similar finding of raised PCT (ng/dl) of (n) $5.1 \pm 7.3$ in $47 \%$ in their study. Thus, according to the various studies PCT is a good marker even for urosepsis.

On ultrasound of CKD patients having urosepsis, the most common finding was acute pyelonephritis (APN) $25(25 \%)$ followed by small kidney which was present in $15 \%$, cystitis and renal stone $11(11 \%)$ each, stent is situ and ureteric calculus with $\mathrm{HN} \mathrm{HU}$ was finding present in $9(9 \%)$ patients and renal abscess present in $7(7 \%)$. Renal papillary necrosis was present in $6(6 \%)$ patients of $3(3 \%)$ patient had emphysematous pyelonephritis whereas $2(2 \%)$ patient each had prostatic abscess and bladder tumor in CKD patients having urosepsis in the study.

These findings were consistent with Tambo et al., ${ }^{8}$ Sørensen et al., ${ }^{19}$ Ruiz-Mesa et al., ${ }^{20}$ and Buonaiuto et al. ${ }^{10}$ 
In the present study, sepsis led to mortality in $10.6 \%$ of patients of sepsis; however, mortality was found in 58.8\% patients of uroseptic shock thus uroseptic shock causes more mortality than urosepsis alone. Lee et al., ${ }^{21}$ also found similar results, sepsis-related mortality was (4.9) in healthcare associated (HCA) whereas hospital associated (HOA) caused $(14.6 \%)$ death. However, total mortality at discharge in there study was HCA $(9.8 \%)$ mortality and HOA (41.5\%) mortality.

Padkin et al., ${ }^{22}$ reported $47.3 \%$ mortality, but their study only includes severe sepsis that occurred during the first $24 \mathrm{~h}$ after intensive care unit admission.

Furthermore, Ferrer et al., ${ }^{23}$ in a recent article on outcome of a nationwide educational intervention based on the Surviving Sepsis Campaign guidelines, reported a basal hospital mortality rate of 44\%. Degoricija et al., ${ }^{24}$ also found mortality rate for sepsis as $17 \%$, severe sepsis $33.7 \%$, septic shock $72.1 \%$, and multiple organ dysfunction syndrome $74.4 \%$.

\section{Limitations of the study}

We could study only 100 patients. By increasing the sample size, prevalence of CKD could have been stidied.

\section{CONCLUSION}

All patients had albuminuria and pyuria. Abundant pus cells were present in 38\% patients. The maximum number of patients belonged to CKD Stage 3 (eGFR-30-59). On ultrasonography, APN (25\%) was the most common cause of urosepsis. Thorough pathological, microbiological, and radiological investigations are important to assess the damage and to start early treatment.

\section{ACKNOWLEDGMENT}

We are thankful to nursing staff of ACPM Medical College Dhule, for their entire support while carrying out the study.

\section{REFERENCES}

1. Codreanu I, Perico N, Sharma SK, Schieppati A and Remuzzi G Prevention programmes of progressive renal disease in developing nations. Nephrology. 2006;11(4):321-328. https://doi.org/10.1111/j.1440-1797.2006.00587.x

2. Mathew $T$ and Chronic Kidney Disease (CKD). Management in General Practice Guidance and Clinical Tips to Help Identify, Manage and Refer Patients with CKD in Your Practice. $3^{\text {rd }}$ ed. Australia: Kidney Health Australia; 2015. p. 6.

3. Levey AS, Coresh J, Bolton K, Culleton B, Harvey KS, Ikizler TA, et al. K/DOQI clinical practice guidelines for chronic kidney disease: Evaluation, classification, and stratification. Am J Kidney Dis. 2002;39 Suppl 2:S1-S266.

4. Bhattacharjee K, Das D, Rabha P, Kalwar AK, Kar G and Bhattacharjee P. A study on hematological profile in patients of chronic renal failure with special reference to serum iron profile. J Evid Based Med Healthc. 2015;2(46):8212-8219.

5. Sathyan S, George S, Vijayan P. Prevalence of anemia and cardiovascular diseases in chronic kidney disease patients: A single tertiary care centre study. Int J Adv Med. 2017;4(1):247-251. https://doi.org/10.18203/2349-3933.ijam20170120

6. Afshar R, Sanavi S, Salimi J and Ahmadzadeh M. Hematological profile of chronic kidney disease (CKD) patients in Iran, in predialysis stages and after initiation of hemodialysis. Saudi J Kidney Dis Transpl. 2010;21(2):368-371.

7. James MT, Laupland KB, Tonelli M, Manns BJ, Culleton BF and Hemmelgarn BR. Risk of bloodstream infection in patients with chronic kidney disease not treated with dialysis. Arch Intern Med. 2008;168(21):2333-2339.

https://doi.org/10.1159\%2F000330673

8. Tambo M, Okegawa T, Shishido T, Higashihara E and Nutahara K. Predictors of septic shock in obstructive acute pyelonephritis. World J Urol. 2014;32(3):803-811. https://doi.org/10.1007/s00345-013-1166-4

9. Mansur A, Mulwande E, Steinau M, Bergmann I, Popov AF, Ghadimi M, et al. Chronic kidney disease is associated with a higher 90-day mortality than other chronic medical conditions in patients with sepsis. Sci Rep. 2015;5:10539.

https://doi.org/10.1038\%2fsrep10539

10. Buonaiuto VA, Marquez I, de Toro I, Joya C, Ruiz-Mesa JD, Seara $R$, et al. Clinical and epidemiological features and prognosis of complicated pyelonephritis: A prospective observational single hospital-based study. BMC Infect Dis. 2014;14(1):639. https://doi.org/10.1186\%2Fs12879-014-0639-4

11. Umesha L, Shivaprasad SM, Rajiv EN, Kumar MS, Leelavathy V, Sreedhara CG, et al. Acute pyelonephritis: A single-center experience. Indian J Nephrol. 2018;28(6):454-461. https://doi.org/10.4103/ijn.IJN_219_16

12. Wang HE, Gamboa C, Warnock DG and Muntner P. Chronic kidney disease and risk of death from infection. Am J Nephrol. 2011;34(4):330-336 https://doi.org/10.1159/000330673

13. van Nieuwkoop C, Bonten TN, van't Wout JW, Kuijper EJ, Groeneveld $\mathrm{GH}$, Becker $\mathrm{MJ}$, et al. Procalcitonin reflects bacteremia and bacterial load in urosepsis syndrome: A prospective observational study. Crit Care. 2010;14(6):R206. https://doi.org/10.1186\%2Fs12879-019-3789-6

14. Meisner M. Update on procalcitonin measurements. Ann Lab Med. 2014;34(4):263-273. https://doi.org/10.3343/alm.2014.34.4.263

15. Uzzan B, Cohen R, Nicolas P, Cucherat M and Perret GY. Procalcitonin as a diagnostic test for sepsis in critically ill adults and after surgery or trauma: A systematic review and metaanalysis. Crit Care Med. 2006;34(7):1996-2003. https://doi.org/10.1097/01.CCM.0000226413.54364.36

16. Sugimoto $\mathrm{K}$, Adomi $\mathrm{S}$, Koike $\mathrm{H}$ and Esa A. Procalcitonin as an indicator of urosepsis. Res Rep Urol. 2013;5:77-80. https://doi.org/10.2147/RRU.S42711

17. Luzzani A, Polati E, Dorizzi R, Rungatscher A, Pavan R and Merlini A. Comparison of procalcitonin and C-reactive protein as markers of sepsis. Crit Care Med. 2003;31(6):1737-1741. 
https://doi.org/10.1097/01.CCM.0000063440.19188.ED

18. Simon L, Gauvin F, Amre DK, Saint-Louis P and Lacroix J. Serum procalcitonin and C-reactive protein levels as markers of bacterial infection: A systematic review and meta-analysis. Clin Infect Dis. 2004;39(2):206-217.

https://doi.org/10.1086/421997

19. Sørensen SM, Schønheyder HC and Nielsen H. The role of imaging of the urinary tract in patients with urosepsis. Int J Infect Dis. 2013;17(5):e299-e303.

https://doi.org/10.1016/j.ijid.2012.11.032

20. Divatia JV, Amin PR, Ramakrishnan N, Kapadia FN, Todi S, Sahu S, et al. Intensive care in India: The Indian intensive care case mix and practice patterns study. Indian J Crit Care Med. 2016;20(4):216-225.

https://doi.org/10.4103/0972-5229.180042

21. Lee JC, Lee NY, Lee HC, Huang WH, Tsui KC, Chang CM, et al. Clinical characteristics of urosepsis caused by extendedspectrum beta-lactamase-producing Escherichia coli or
Klebsiella pneumonia and their emergence in the community. J Microbiol Immunol Infect. 2012;45(2):127-133

https://doi.org/10.1016/j.jmii.2011.09.029

22. Padkin A, Goldfrad C, Brady AR, Young D, Black N and Rowan K. Epidemiology of severe sepsis occurring in the first $24 \mathrm{hrs}$ in intensive care units in England, Wales, and Northern Ireland. Crit Care Med. 2003;31(9):2332-2338 https://doi.org/10.1097/01.CCM.0000085141.75513.2B

23. Ferrer R, Martin-Loeches I, Phillips G, Osborn TM, Townsend S, Dellinger RP, et al. Empiric antibiotic treatment reduces mortality in severe sepsis and septic shock from the first hour: Results from a guideline-based performance improvement program. Crit Care Med. 2014;42(8):1749-1755. https://doi.org/10.1097/CCM.0000000000000330

24. Degoricija V, Sharma M, Gradišer M, Šefer S, Vučičević Ž. Analysis of primary urosepsis in medical intensive care unit in University Hospital: Intensive care unit survival and the effect of antimicrobial therapy. In: Osmi Simpozij o Spolno Prenosivim Bolestima i Urogenitalnim Infekcijama, Simpozij Slavka Schenwalda; 2006.



